\title{
SOLAR TRACKING DUAL - AXIS BERBASIS ARDUINO UNO DENGAN MENGGUNAKAN LENSA FRESNEL GUNA MENINGKATKAN EFISIENSI PENGFOKUSAN CAHAYA MATAHARI
}

\author{
Margana, S.T., M.Eng. ${ }^{1)}$ \\ Teknik Konversi Energi, Politeknik Negeri Semarang, Indonesia ${ }^{1}$
}

\begin{abstract}
Abstrak
Solar Tracking Dual-Axis Berbasis Mikrokontroler dengan Menggunakan Lensa Fresnel Guna Meningkatkan Efisiensi Pemfokusan Cahaya Matahari ini merupakan sebuah alat yang dirancang untuk mengarahkan Solar cell ke cahaya matahari. Alat ini bekerja dengan menggunakan 4 buah sensor LDR (Light Dependent Resistor) dan dua Motor Servo MG996 sebagai aktuator/penggeraknya. Sistem ini dikendalikan oleh Arduino Nano yang menjalankan program yang ditanamkan oleh software Arduino IDE (Integrated Development Environment).

Hasil pengujian menunjukkan perbandingan tegangan dan arus yang dihasilkan Solar cell, sehingga dapat dihitungan nilai daya yang dihasilkan. Daya maksimum pada Solar Tracking (Pmax) dengan menggunakan lensa Fresnel sebesar 6,865 Watt dan tanpa lensa Fresnel sebesar 5,987 Watt. Pada Solar Tracking dengan menggunakan lensa Fresnel nilai efisiensinya sebesar 68,65 \% dan tanpa lensa Fresnel nilai efisiensinya sebesar 59,9\%. Dari hasil tersebut menunjukkan bahwa efisiensi yang dihasilkan Solar cell dengan lensa Fresnel lebih baik dibanding tanpa menggunakan lensa Fresnel.

Kata kunci : efisiensi, Solar Tracking, mikrokontroler, Arduino
\end{abstract}

\section{Pendahuluan}

Kebutuhan energi dunia akhir- akhir ini sangat meningkat tajam, terutama dengan munculnya negaranegara industri raksasa. "Peningkatan ini akan sangat terasa pada dekade- dekade awal abad ke-21. Sebagai contoh, pada tahun 2000 kebutuhan energi listrik dunia mencapai 7-8 triliyun KWH dan diprediksikan pada tahun 2020 kebutuhan akan mencapai 14,5 triliyun KWh". (Purwanto, Yuliman. 2004)

Letak geografis Indonesia yang berada di ekuator menyebabkan Indonesia adalah salah satu daerah yang memiliki nilai surplus sinar matahari karena mendapat sinar matahari sepanjang tahun. "Hampir seluruh daerah di Indonesia berpotensi untuk dikembangkan PLTS dengan daya rata-rata mencapai $4 \mathrm{kWh} / \mathrm{m} 2$. Kawasan barat Indonesia memiliki distribusi penyinaran sekitar $4,5 \mathrm{kWh} / \mathrm{m} 2 /$ hari dengan variasi bulanan $10 \%$ sementara kawasan timur Indonesia berpotensi penyinaran sekitar $5,1 \mathrm{kWh} / \mathrm{m} 2 /$ hari dengan variasi bulanan sekitar $9 \%$. Hal ini perlu dimanfaatkan dengan baik dengan percepatan pembangunan pembangkit listrik

tenaga surya di berbagai daerah yang berpotensi di seluruh kawasan Indonesia". (Fadhil Firdaus, Muhammad. 2017)

Dalam tugas akhir ini akan dilakukan inovasi dari teknologi photovoltaic (PV) yang masih terkendala pada nilai efisiensi yang belum maksimal.

Dengan penambahan inovasi sistem tracking berbasis microcontroller Arduino nano dan lensa fresnel pada photovoltaic (PV)

akan memaksimalkan energi matahari yang masuk pada photovoltaic (PV), sehingga dapat meningkatkan efisiensi dari photovoltaic (PV).

\section{Metode Penelitian}

Penulis menggunakan beberapa metode penelitian untuk mengarahkan penelitian (perancangan) ini agar tujuan penelitian yang telah ditentukan dapat tercapai Bahan - bahan yang digunakan untuk membuat sistem ini sebagai berikut:

a). 4 buah Sensor LDR yang dipasang disisi solar cell, digunakan untuk mendeteksi posisi matahari.

b). Panel surya, yang digunakan untuk merubah energi matahari menjadi energi listrik.

c). Mikrokontoler Arduino Nano

d). LCD 2x16, untuk menampilkan hasil pengukuran secara digital.

e). 2 buah Servo MG995 sebagai penggerak posisi panel surya pada posisi sumbu $-\mathrm{X}$ dan sumbu-Z

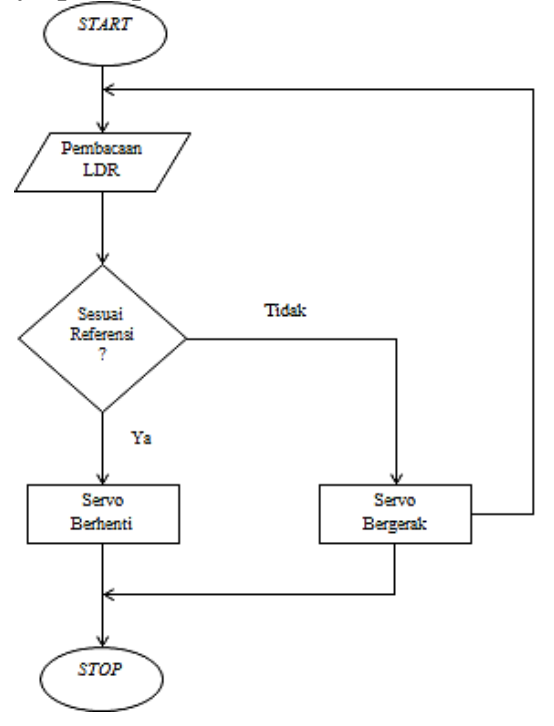




\section{Data pengujian dan penghitungan}

Berikut ini adalah data hasil pengujian yang ditunjukkan seperti pada tabel dibawah ini:

Tabel 4.1 Data pengujian nilai tegangan dan arus dengan menggunakan lensa dan tidak menggunakan lensa.

\section{Analisa Data}

Grafik dibuat untuk mempermudah analisa data pengujian dan hasil pengujian. Pada Tugas Akhir ini data yang diambil adalah hasil dari variasi solat tracking dengan menggunakan lensa fresnel dan tanpa menggunakan lensa fresnel.

Karakteristik Arus Terhadap Waktu dengan Menggunakan Lensa Fresnel dan Tidak Menggunakan Lensa Fresnel

Gambar hubungan arus terhadap waktu pada solar tracking dengan menggunakan lensa fresnel dan tidak menggunakan lensa fresnel ditunjukkan pada gambar berikut ini



WAKTU (MB)



Gambar Grafik Arus Terhadap Waktu dengan Menggunakan Lensa Fresnel dan tanpa Lensa Fresnel

Gambar diatas menunjukan karakteristik dari nilai arus yang dihasilkan solar tracking. Dari pengambilan data diatas diambil dengan lama 3,5 jam pada jam 10.10 WIB - 14.30 WIB dengan pengambilan data setiap 10 menit sekali. Dari kedua variasi pada grafik diatas menunjukkan bahwa nilai arus yang dihasilkan dengan menggunakan lensa fresnel jauh lebih baik dengan tidak menggunakan lensa fresnel, hal tersebut terlihat jika dengan menggunakan lensa fresnel penurunan atau kenaikan nilai arusnya jauh lebih stabil dibanding dengan tidak menggunakan lensa fresnel yang cenderung memilliki penurunan dan kenaikan nilai arus yang signifikan dikarenakan dengan menggunakan lensa fresnel cahaya matahari yang masuk solar cell akan lebih besar dibanding dengan tidak menggunakan lensa fresnel sehingga dapat mempengaruhi dari nilai arus yang masuk kedalam solar cell. Dengan menggunakan lensa fresnel nilai arus terkecil yang dihasilkan pada solar cell adalah sebesar 0,48 A yaitu pada jam 11:50:00, 13:20:00, dan 14:30:00. Sedangkan nilai arus terbesar yang dihasilkan yaitu sebesar 0,55 A yaitu pada jam 10:40:00, dan 11:10:00. Sedangkan dengan tidak menggunakan lensa fresnel arus terkecil yang dihasilkan yaitu sebesar 0,37 A yaitu pada jam 11:50:00, 12:00:00,

12:20:00, dan 14:30:00. Untuk nilai arus terbesar yaitu sebesar 0,55 A yaitu pada jam 10:40:00.

Karakteristik Tegangan Terhadap Waktu dengan Menggunakan Lensa

Fresnel dan Tidak Menggunakan Lensa Fresnel

Gambar karakteristik tegangan terhadap waktu pada solar tracking dengan menggunakan lensa fresnel dan tidak menggunakan lensa fresnel ditunjukkan pada gambar 4.2 berikut ini adalah gambar 4.2 :

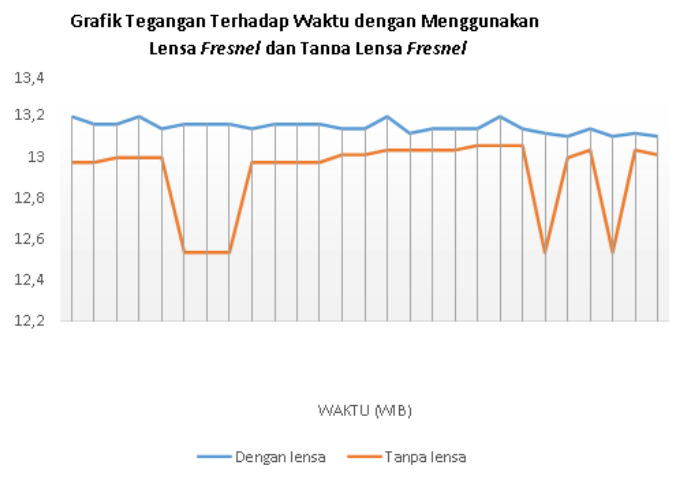

Gambar Grafik Tegangan Terhadap Waktu dengan Menggunakan Lensa Fresnel dan Tanpa Lensa Fresnel

Gambar diatas menunjukan karakteristik nilai tegangan terhadap waktu pada solar cell dengan menggunakan lensa fresnel dan tidak menggunakan lensa fresnel. Pada jam 10.10 untuk solar cell dengan menggunakan lensa fresnel memiliki nilai tegangan sebesar 13,14 Volt, sedangkan dengan tidak menggunakan lensa fresnel sebesar 12,84 . Untuk nilai tegangan terendah dengan menggunakan lensa fresnel yaitu sebesar 13,01 Volt pada jam 13:50:00, 14:10:00, dan 14:30:00. Sedangkan nilai tegangan terbesar yaitu sebesar 13,14 Volt yaitu pada jam 10:10:00, 10:40:00, 12:30:00, dan 13:20:00. Untuk nilai tegangan terendah tanpa menggunakan lensa

fresnel yaitu sebesar 12,25 Volt yaitu pada jam 11:00:00, 11:10:00, 11:20:00, dan 14:10:00.

Sedangkan nilai tegangan tertinggi yaitu sebesar 12,95 Volt yaitu pada jam 13:10:00, 13:20:00, dan 13:30:00. Hal tersebut dikarenakan dengan penggunaan lensa fresnel, sinar matahari yang masuk ke solar cell lebih terfokuskan sehingga cahaya matahari yang masuk akan lebih tinggi dibanding dengan tidak menggunakan lensa fresnel. Disamping itu faktor dari cuaca dan kondisi permukaan solar cell yang tidak terhalang oleh objek lain juga mempengaruhi nilai dari tegangan yang dihasilkan, jika pada saat matahari tertutup awan secara tiba-tiba hal tersebut akan mempengaruhi nilai tegangan yang dihasilkan dikarnakan intensitas atau cahaya matahari akan tertutup oleh awan, selain tertutup oleh awan, objek- 
objek seperti daun dan gedung-gedung yang dapat menutupu sinar matahari juga dapat mempengaruhi nilai tegangan yang dihasilkan solar cell.

Karakteristik Daya Sistem Tracking Terhadap Waktu dengan Menggunakan Lensa Fresnel dan Tidak Menggunakan Lensa Fresnel

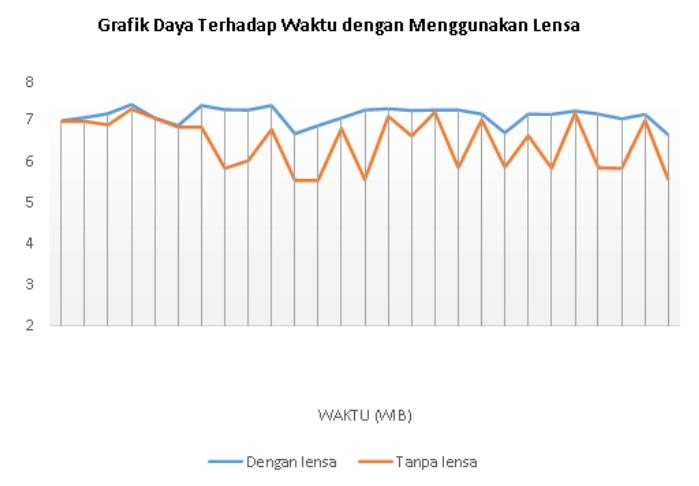

Gambar Grafik Daya Terhadap Waktu dengan Menggunakan Lensa Fresnel dan Tanpa Lensa Fresnel

Gambar diatas menggambarkan karakteristik dari nilai daya yang dihasilkan solar cell terhadap waktu. Dari hasil data pengujian dan grafik diatas dapat diketahui bahwa daya yang dihasilkan oleh solar cell dengan menggunakan lensa fresnel jauh lebih tinggi dibandingkan tanpa menggunakan lensa fresnel. Sedangkan penurunan dan kenaikan pada solar cell dengan menggunakan lensa fresnel jauh lebih stabil dibandingkan tanpa menggunakan lensa fresnel yang nilai penurunan dan kenaikan dayanya tidak begitu stabil. Untuk nilai daya terendah solar cell dengan menggunakan lensa yaitu sebesar 7,227 Watt yaitu pada jam 10:40:00, untuk nilai daya terendah sebesar 6,283 Watt yaitu pada jam 11:50:00. Sedangkan nilai tegangan tertinggi untuk solar cell tanpa menggunakan lensa sebesar 6,977 Watt yaitu pada jam 12:50:00, untuk nilai terendahnya sebesar 4,751 Watt yaitu pada jam 11:50:00 dan 12:00:00.

Karakteristik Intensitas Matahari Terhadap Waktu

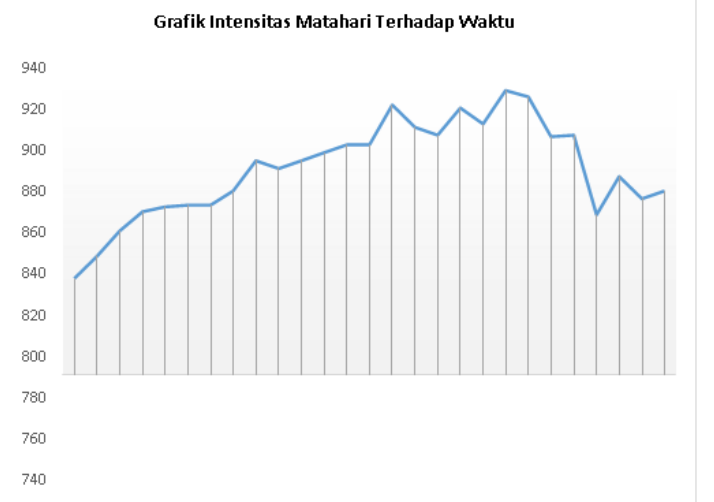

Gambar Grafik Intensitas Matahari Terhadap Waktu

Gambar 4.4 menunjukkan karakteristik intensitas matahari pada jam tertentu. Intensitas matahari pada umumnya tiap menit akan berubah-ubah dan tergantung dengan kondisi dari cuaca pada saat itu. Intensitas cahaya matahari pada gambar 4.4 memiliki nilai tertinggi pada kisaran jam 12 siang dan puncak terendahnya pada pagi hari dan sore hari. Pada gambar 4.4 diatas dapat diketahui bahwa nilai intensitas matahari terkecil pada saat pengambilan data sebesar $800 \mathrm{~W} / \mathrm{m} 2$ yaitu pada jam 10:10:00, sedangkan nilai intensitas terbesar sebesar $918 \mathrm{~W} / m 2$ yaitu pada jam 13:20:00

\section{Kesimpulan}

Berdasarkan hasil pengujian dan analisa kinerja dari alat didapatkan karakteristik kinerja dari alat yang telah dibuat dengan variasi solar tracking menggunakan lensa fresnel dan tanpa lensa fresnel sebagai berikut:

1. Daya maksimum pada solar tracking (Pmax) dengan menggunakan lensa fresnel sebesar 6,865 Watt dan tanpa lensa fresnel sebesar 5,987 Watt. Nilai efisiensi pada solar tracking dengan menggunakan lensa fresnel sebesar 68,65\% dan tanpa lensa fresnel sebesar $59,9 \%$.

2. Berdasarkan hasil penghitungan, nilai selisih efisiensi $\left(\Delta \prod\right)$ solar tracking dengan menggunakan lensa fresnel dan tanpa lensa fresnel sebesar $8,777 \%$

3. Nilai daya yang dibutuhkan untuk sistem elektronik / control sebesar 1,35467 Watt.

4. Dari hasil analisa didapatkan nilai daya dengan menggunakan lensa fresnel lebih baik dibanding dengan tanpa menggunakan lensa fresnel yaitu 6,865 Watt dengan 5,987 Watt.

\section{Daftar Pustaka}

7. 2015. Introduction of ACS712 Current Sensor Module-30A. With Arduino.

8. Datasheet ACS712. Jurnal ilmiah diakses pada 3 Juni 2018.

9. 2015. Menaikan tegangan atau menurunkan tegangan DC to DC dengan LM2596 dan CN6009 untuk DC to DC. Obengplus. http://obengplus.com/artikel/articles/226/1/Menai kan-tegangan-atau- menurunkan-tegangan-DC-toDC-dengan-LM2596-dan-CN6009-untuk--DC-toDC.html. Diakses pada 3 Juni 2018.

10. . 2016. Mengenal Arduino Nano. Cyber Code. http://familycybercode.blogspot.com/2016/01/mengenalarduino-nano.html. Diakses pada 1 Juni 2018.

11. 2017. Tutorial Arduino mengakses module RTC DS3231. Nyebar Ilmu.

https://www.nyebarilmu.com/tutorial-arduinomengakses-module-rtc-ds3231/ Diakses pada 3 Juni 2018.

12. 2018. Cara mengakses module micro SD menggunakan Arduino. Nyebar Ilmu. https://www.nyebarilmu.com/cara-mengaksesmodule-micro-sd- menggunakan-arduino/. Diakses pada 2 Juni 2018. 
13. 2018. Spesifikasi Servo Tower Pro MG995. Mikron123. http://www.mikron123.com/index.php/vmchk/Mo tor-Servo/Servo-Tower-Pro- MG995/Detailedproduct-flyer.html. Diakses pada 1 Juni 2018.

14. 2018. "Jenis panel surya". http://www.panelsurya.com/index.php/index.php/i d/panel-surya-solar-cells/panel- surya-solar-cellstype. Diakses pada 2 Juni 2018.

15. Aldi, Arjuna. 2017. Preview LM2596 Step Down Module.

16. https://arjunaldi.staff.telkomuniversity.ac.id/previ ew-lm2596-step-module/. Diakses pada 4 Juni 2018.

17. Fadhil Firdaus, Muhammad. 2017. "Kajian Potensi Energi Surya di Indonesia”. https://icareindonesia.org/kajian-potensi-energi-surya-diindonesia-2/. (Diakses pada 2 Juni 2018)

18. Khoirunisa, Isnaini. 2016. Kekurangan Dan Kelebihan Memasang Panel Surya. https://www.rumah.com/beritaproperti/2016/5/126421/kekurangan-dankelebihan-memasang-panel-surya. Diakses pada 1 Juni 2018.

19. Rizal F., Ira D. S., Yuwaldi A. 2015. Pemantauan Parameter Panel Surya Berbasis Arduino secara Real Time. Jurnal Rekayasa Elektrika. Vol. 11 hal. 123-

20. Munandar, Aris. 2012. LCD (Liquid Crystal Display). http://www.leselektronika.com/2012/06/liguidcrystal-display-lcd-16-x-2.html.

21. Diakses pada 2 Juni 2018
22. Nisa, Sayyidah Khoirul. 2013. PROTOTIPE DUAL AXIS SUN TRACKER DENGAN SENSOR LDR (LIGHT DEPENDENT RESISTOR) MENGGUNAKAN

23. ARDUINO UNO. Yogjakarta: e-Jurnal D3 ELEKTRONIKA DAN INSTRUMENTASI Universitas Gadjah Mada.

24. Pradana, Sunu. 2017. Micro SD Adapter. https://sunupradana.info/tkr/2017/07/25/micro-sdadapter/. Diakses pada 4 Juni 2018.

25. Purwanto, Yuliman. 2004. "Alternatif Baru Sumber Energi Listrik untuk Masa Depan”. http://www.energi.lipi.go.id/utama.cgi?cetakartike 1\&1101091976 (Diakses pada 2 Juni 2018)

26. Raj, Aswinth. 2015. Pinout and Pin Description of 16x2 LCD Module.

27. https://circuitdigest.com/article/16×2-lcd-displaymodule-pinout-datasheet. Diakses pada 2 Juni 2018.

28. Simatupang, S., Susilo B., dan Hermanto M.B. 2012. Rancang Bangun dan Uji Coba Solar Tracker pada Panel Surya Berbasis Mikrokontroler Atmega16, Jurnal Keteknikan Pertanian Tropis dan Biosistem. Malang: Universitas Brawijaya.

29. Wildian, Roni Syafrialdi. 2015. "SOLAR TRACKER BERBASIS MIKROKONTROLER ATmega8535 dengan sensor LDR dan penampil LCD. Padang: Jurnal fisika Universitas Andalas. 